\title{
KUNTOUTUKSEN KOULUTUKSEN JA TUTKIMUKSEN KEHITTÄMISEN FOORUMI (KUNFO) ALOITTANUT TOIMINTANSA
}

Kuntoutuksen tutkimuksen ja kehittämisen foorumi (KunFo) aloitti toimintansa huhtikuussa 2021. Foorumin ovat yhteistyössä valmistelleet sosiaali-ja terveysministeriö sekä opetus- ja kulttuuriministeriö.

\section{Foorumi perustuu Kuntoutuskomitean työhön}

Kuntoutuksen uudistamiskomitea (2017) totesi työnsä päätteeksi julkaistussa raportissaan, että kuntoutuksen tutkimus on hajanaista ja verkostoyhteistyö tutkimus-, kehittämis- ja innovaatiotoimintaa toteuttavien toimijoiden välillä on sirpaleista. Kuntoutuksella ei ollut valtakunnallista strategista tutkimus- ja kehittämisohjelmaa. Komitea piti tärkeänä, että ammattikorkeakoulut ja yliopistot suunnittelisivat yhteiset oppisisällöt kuntoutuksen perus-, jatko- ja täydennyskoulutukseen. Komitea piti myös tärkeänä, että korkeakoulut ja muut tutkimusorganisaatiot osallistuvat yhdessä sosiaali- ja terveysministeriön ja työ- ja elinkeinoministeriön kanssa kuntoutuksen strategisen tutkimus- ja kehittämisohjelman laatimiseen. Kuntoutuksen uudistamisen toimintasuunnitelmassa vuosille 2020-2022 yhdeksi kuntoutuksen uudistamisen tavoit- teeksi asetettiin kuntoutuksen koulutuksen ja tutkimuksen foorumin perustamisen opetus- ja kulttuuriministeriön ja sosiaali- ja terveysministeriön yhteistyönä.

\section{Kuntoutuksen osaamis- ja tutkimustarpeet}

Kuntoutuksen osaamistarpeisiin suuntautuu useita ammatillisia tutkintoja ja korkeakoulututkintoja, joista osa tuottaa laaja-alaista osaamista ja osa erikoistunutta osaamista. Kuntoutusosaamista voi sisältyä myös muihin sosiaali- ja terveysalan tutkintoihin. Opetus- ja kulttuuriministeriön mukaan tarvitaan valtakunnallisesti jaettu yhteinen tilannekuva kuntoutuksen ammatti- ja tehtäväkuvista, kuntoutusosaamisen tarpeista ja nykyisten koulutusten ja opintopolkujen toimivuudesta, jotta kuntoutuksen osaamista tuottavista tutkinnoista ja muusta koulutuksesta muodostuvan kokonaisuuden toimintaa voidaan arvioida ja kehittää.

Kuntoutuksen tutkimuksen kokonaiskuvan muodostaminen on haastavaa ottaen huomioon, että alan tutkimusta tehdään useiden tieteenalojen sisällä ja monitieteisesti. Esimerkiksi kuntoutuksen sähköisten palveluiden ja laitekehityksen näkökulmasta tek- 
nisillä tieteillä on tärkeä ja merkitykseltään kasvanut asema kuntoutuksen tutkimuksessa.

\section{KunFolle asetetut tavoitteet ja aikataulu}

Opetus- ja kulttuuriministeriö ja sosiaali- ja terveysministeriö valmistelivat ehdotuksen kuntoutuksen koulutuksen ja tutkimuksen kehittämisfoorumin perustamiseksi vuosille 2021-2023. Kehittämisfoorumin tehtävänä on ennakoida ja kuvata kuntoutuksen osaamistarpeita sosiaali- ja terveydenhuollossa ja tehdä ehdotus siitä, miten koulutus- ja tutkimusjärjestelmää tulee kehittää vastaamaan kuntoutusosaamisen tarpeita. Lisäksi foorumin tehtävänä on käsitellä valtakunnallisella tasolla koko koulutus- ja tutkimusjärjestelmää suhteessa sosiaali- ja terveyspalvelujärjestelmän kehitystarpeisiin.

Kehittämisfoorumi tuottaa suunnitelman kuntoutuksen koulutuksen ja tutkimuksen kehittämiseksi vuosille 2024-2030. Suunnitelmaan sisältyy selvitys työelämän kehittämistarpeista, ehdotukset perustutkintokoulutuksen ja sitä täydentävän koulutuksen rakenteen kehittämisestä sekä ehdotuksen kuntoutuksen tutkimusstrategiaksi. Foorumin kehittämisteemoja ovat kuntoutuksen koulutusten tilannekuva ja rakenne, koulutusten osaamisprofiilit, kuntoutuksen ja sen koulutuksen tutkimus sekä kuntoutusalan työvoimatarve ja sen saatavuus. Suositusten toimeenpanosta päätetään foorumin työskentelyn jälkeen.

Kehittämisfoorumi aloitti toimintansa alkuvuodesta 2021. Kuntoutusalan koulutuksen ja tutkimuksen kehittämisehdotukset julkaistaan marraskuussa 2023.

\section{Foorumin kokoonpano}

Foorumin työtä ohjaa ja johtaa ohjausryhmä, johon kuuluvat puheenjohtajien (tutkimusprofessori Anna-Liisa Salminen, professori Marketta Rajavaara ja professori Olavi Airaksinen) ja asiantuntijasihteerin (erikoisasiantuntija Mari Haverinen) lisäksi opetus- ja kulttuuriministeriön, sosiaali- ja terveysministeriön sekä opetushallituksen edustajat. Foorumin jäseniksi (yhteensä 31) on nimetty henkilöitä, jotka edustavat kattavasti koko koulutusja tutkimusjärjestelmää ja sidosryhmiä.

\section{Foorumin työskentely}

Foorumi kokoontuu 4-5 kertaa vuodessa. Työskentely tapahtuu ensisijaisesti työryhmissä. Vuoden 2021 loppuun saakka KunFossa keskitytään kolmeen teemaan. Osaamis- ja työelämätarpeet ovat foorumin työskentelyn lähtökohta. Tarpeita kartoittavassa työryhmässä selvitetään väestön kuntoutustarpeita, kuntoutuksen työvoimatarpeita ja henkilöstön saatavuutta, sote-uudistuksen vaikutuksia kuntoutuksen osaamis- ja työelämätarpeisiin sekä kuntoutuksen trendejä ja toimintaympäristöjä 2030-luvulla. Koulutuksen nykytilaa kartoittavassa työryhmässä kuvataan kuntoutuksen koulutusten nykytilaa, arvioidaan kuntoutuksen koulutuksen ja opetuksen vahvuuksia ja heikkouksia sekä tarkastellaan kuntoutuksen koulutusta Suomessa suhteessa kansainvälisiin kehityssuuntiin. Tutkimuksen nykytilaa kartoittavassa työryhmässä kuvataan kuntoutuksen tutkimuksen nykytilaa Suomessa, tarkastellaan kansainvälisen tutkimusyhteistyön ja julkaisemisen tilaa Suomessa sekä arvioidaan kuntoutuksen tutkimuksen vahvuuksia ja heikkouksia. Kartoitusten tavoitteena on saavuttaa yhteinen käsitys koulutuksen ja tutkimuksen nykytilasta ja tulevista tarpeista.

Vuoden 2022 alussa aletaan työstää koulutuksen suunnitelmaa ja tutkimusstrategiaa. Tällöin myös työryhmien rakennetta on tarkoitus hiukan muuttaa.

Foorumin jäsenten työskentely on edustuksellista. Jäsenten tehtävä on edustaa omia organisaatioitaan ja sidosryhmiään, viestiä ja viedä tietoa KunFosta edustamilleen tahoille ja vastaavasti tuoda tietoa omista sidosryhmistään KunFon käyttöön. Tämän lisäksi KunFossa pyritään toimimaan siten, että aihepiiristä kiinnostuneet voivat seurata foorumin työtä, ja osallistua siihen esimerkiksi tuottamalla tietoa foorumin käyttöön ja kommentoimalla foorumin tuotoksia työskentelyn eri vaiheissa. Foorumin puheenjohtajiin ja jäseniin voi mielellään olla yhteydessä. 
Foorumin työskentelystä ja jäsenistä löytyy tietoa opetus-ja kulttuuriministeriön sekä sosiaali-ja terveysministeriön sivuilta https://minedu.fi/kunfo, https://stm.fi/kuntoutuksen-uudistus. Työskentelyä voi seurata myös Twitterissä \#KunFo.

Aija Töytäri, TtT, opetusneuvos, Opetus- ja kulttuuriministeriö, Korkeakoulu- ja tiedepolitiikan osasto

Seija Sukula, FT, erityisasiantuntija, Sosiaali- ja terveysministeriö, Sosiaaliturva-ja vakuutus-

osasto

Anna-Liisa Salminen, PhD, tutkimusprofessori, Kelan tutkimus 